$\begin{array}{lll}\text { KULTURA } & \begin{array}{l}\text { POLSKA AKADEMIA NAUK } \\ \text { KOMITET SOCJOLOGII }\end{array} & \text { ISSN 0023-5172 } \\ \text { i } & \begin{array}{l}\text { INSTYTUT STUDIÓW POLITYCZNYCH } \\ \text { SPOLECLNSTMO }\end{array} & \\ 2011, \text { nr 2-3 SOCJOLOGIA KULTURY } & \end{array}$

TOMASZ KOZŁOWSKI

Wyższa Szkoła Nauk Humanistycznych i Dziennikarstwa w Poznaniu

\title{
ELEMENTY TRANSMISJI PROTOKULTUROWEJ W SPOŁECZEŃSTWIE KONSUMPCYJNYM
}

W pracach zoologów, etologów kognitywnych, zoopsychologów i badaczy zachowań naczelnych często można trafić na opisy zachowań, które z punktu widzenia nauk humanistycznych należałoby uznać za przejaw funkcjonowania stricte kulturowego. Według psycholingwistki Jean Aitchison (2002), ale także etologa Donalda Griffina (2003), podstawowe kryterium symbolu (a co za tym idzie - języka), konwencjonalność, spełnia na przykład taniec pszczół. Z bardzo podobną sytuacją mamy do czynienia $\mathrm{w}$ przypadku wielokrotnie odnotowanych i opisanych zawołań małp, rezusów, które krzycząc w określony sposób ostrzegają się nawzajem o czyhającym niebezpieczeństwie (ale także o jego rodzaju). Jak wskazuje Jared Diamond (1998), odnotowano dotychczas kilka grup sygnałów, z których wyraźnie można wyodrębnić co najmniej trzy: „sygnalizujące" węża (zagrożenie nadrzewne), lamparta (niebezpieczeństwo naziemne) czy orła (atak z powietrza). Małpy mają również zróżnicowaną terytorialnie „tradycję” zdobywania pożywienia (zob. Blackmore 2002; Tomasello 2002).

\section{„KULTURY” ZWIERZĘCE I PROTOKULTURY WŚRÓD LUDZI}

Zgodnie z założeniami psychologii ewolucyjnej, podobne formy zachowań nie stanowią jednak zachowań kulturowych. Są to - co najwyżej formy określane mianem protokultur, czyli całości opartych na mechanizmie społecznego uczenia się, który jest strategią jakościowo odmienną od naśladownictwa i transmisji kulturowej. Kluczowe - z punktu widzenia paradygmatu psychoewolucyjnego - jest funkcjonowanie oraz wykorzystywanie przez jednostki tzw. modułu teorii umysłu (ang. theory of mind module; zob. Ba-

Adres do korespondencji: tomasz.kozlowski@wsnhid.pl 
ron-Cohen 1997; Gopnik, Meltzoff, Kuhl 2004). Moduł teorii umysłu to jeden $z$ wielu elementów wchodzących w skład wyposażenia naszego umysłu ${ }^{1}$. Teoria umysłu to zdolność rozumienia, że inne osoby mają umysł działający na takich samych zasadach jak nasz.

Praktyka badawcza wskazuje, że istnienie takiej zdolności niezwykle trudno stwierdzić w przypadku zwierząt. Niewykluczone, że jest ona właściwa tylko ludziom, choć niektóre eksperymenty i obserwacje nie pozwalają jednoznacznie wykluczyć jej w przypadku niektórych naczelnych (w szczególności najbliższych człowiekowi - szympansów), kilku gatunków waleni oraz słoni. Nie licząc jednak owych kilku dyskusyjnych przypadków, badacze zachowań zwierząt są zgodni, że głównym czynnikiem zachowań zwierząt względem innych jest rozumienie intencji na podstawie obserwowania konkretnych zachowań, w szczególności manifestacji stanów emocjonalnych ${ }^{2}$. Oznacza to, że zwierzę jest w stanie zrozumieć zamiar innego zwierzęcia tylko wówczas, gdy towarzyszy mu określone, obserwowane zachowanie. Mówienie zatem o „rozumieniu zamiaru” jest tutaj określeniem na wyrost. Zamiar jest stanem psychicznym, a dopiero teoria umysłu umożliwia ich przewidywanie i rozumienie.

U zwierząt (również wśród ludzi) brak teorii umysłu skutkuje znacznym ograniczeniem zdolności rozumienia sytuacji społecznych, nie oznacza to jednak, że u takich podmiotów niemożliwe jest wykształcenie pewnych nawyków, które mogą kojarzyć się ze zjawiskami kulturowymi. Choć mogą one sprawiać wrażenie zachowań złożonych, uwzględniających kompleksowość warunków zewnętrznych, obecność partnerów interakcji czy istnienie pewnych konwencji, działania te można wyjaśniać w sposób stosunkowo prosty, bez odwoływania się do terminologii stricte kulturowej.

Michael Tomasello wymienia co najmniej kilka ciekawych mechanizmów protokulturowej transmisji wzorów zachowań ${ }^{3}$. Z psychologicznego punktu

${ }^{1}$ Jak wskazywał Jerry Fodor (1983), każdy z modułów, niczym różne ostrza szwajcarskiego scyzoryka, służy rozwiązywaniu konkretnego problemu, co sprzeczne jest zarówno z poglądem empirystów, przyjmowanym za dogmat przez skrajnych kulturalistów ze szkoły Franza Boasa, że psychika ludzka to tabula rasa, na której społeczeństwo, kultura i historia zapisują nowe rozdziały. Według psychologii ewolucyjnej owa „czysta tablica” jest w znacznej części zapisana przez dziedzictwo bio-ewolucyjne. $Z$ jednej strony zatem umysł, po pierwsze, nie jest w stanie nauczyć się wszystkiego, po drugie, jest z góry przystosowany do przyjęcia określonych ścieżek rozwojowych. Jednym $z$ elementów zaprogramowanych $\mathrm{w}$ nas genetycznie jest właśnie moduł teorii umysłu, zdolność wykształcana $\mathrm{z}$ reguły w okolicach trzeciego-czwartego roku życia.

2 Simon Baron-Cohen (1997) określa tę zdolność mianem detektora intencjonalności (intentionality detector).

${ }^{3}$ Jednym z nich jest tzw. rytualizacja ontogenetyczna. „Proces ten - według Tomasello (2002, s. 46) - polega na tworzeniu sygnału komunikacyjnego przez dwa osobniki, kształtujące wzajemnie swoje zachowanie podczas powtarzających się interakcji społecznych. Na przykład noworodek, chcąc ssać, może z początku kierować się prosto do piersi matki, przypadkiem po drodze chwytając ją za ramię. Przy następnej okazji matka może przewidywać zachowanie dziecka już przy dotknięciu ramienia i może nawet mu pomagać podając pierś, co z kolei spowo- 
widzenia są to jednak formy autotresury, która nie ma nic wspólnego z pojęciem naśladownictwa czy internalizacji. Naśladownictwo z kolei jest procesem daleko bardziej wysublimowanym niż „społeczne tresowanie”. Susan Blackmore (2002) ów jakościowy przeskok porównuje do przygotowywania zupy z przepisu zamiast gotowania jej z pamięci, jedynie na podstawie wrażeń smakowych. Innymi słowy, ażeby naśladować - i to właśnie jest kryterium, które z punktu widzenia psychologii ewolucyjnej można uznać za determinantę dziedziczenia stricte kulturowego - należy uświadamiać sobie dokładnie sens, cel oraz przebieg wykonywanej/obserwowanej czynności (elementy, których rozumienie umożliwia teoria umysłu).

Specyfika zachowań osób bez teorii umysłu dobrze uwidacznia się w sposobie funkcjonowania dzieci do 3-4 roku życia. Zazwyczaj nie rozumieją one, że ktoś inny może myśleć lub wiedzieć coś innego niż one same (Witkowski 2005). W takich okolicznościach niezwykle trudno jest mówić o procesach internalizacji norm. W charakterystyce zachowań małych dzieci znaczną rolę odgrywają myślenie skojarzeniowe, uleganie emocjom, zachowania oparte na zasadzie bodziec-reakcja czy bardzo znacznie ograniczona perspektywa czasowo-przestrzenna (brak pojęć w rodzaju „kiedyś”, „gdzieś”; opieranie się na „tu” i „teraz”), ograniczenie roli samoświadomości ${ }^{4}$.

Nie ulega wątpliwości, że mimo tych ograniczeń poznawczych małe dzieci często potrafią reagować adekwatnie do określonego kontekstu społecznego. Rozumieją proste komunikaty werbalne, potrafią wykonać niektóre polecenia, same zasygnalizują swoje potrzeby. Mechanizm tych działań jest jednak bardzo daleki od czegokolwiek, co można by określić mianem rezultatu internalizacji norm czy myślenia symbolicznego (zob. Damasio 2000, 2002). Polega on raczej na zasadzie skojarzeń, wykorzystania wzorów zachowań, które zostały stosownie wzmocnione - lub przeciwnie, wyciszone - dzięki występowaniu określonych emocji, pozytywnych bądź negatywnych, i dlatego odznaczają się bardzo niewielką plastycznością. Jak wskazują badania, umysły dzieci bez teorii umysłu działają na zasadzie reflektora, który wyłapuje jedynie fragment otoczenia, podczas gdy cała reszta umyka (zob. Edelman 1998). Świadomość działająca na tej zasadzie nie potrafi jeszcze tworzyć większych całości, obejmujących szerszy wycinek czasoprzestrzenny, pozbawiona jest równocześnie

duje, że w kolejnych interakcjach dziecko ograniczy się do dotknięcia ramienia mamy i oczekiwania na jej reakcję (wtedy "dotknięcie ramienia» wygląda na sygnał wykonany w określonej intencji). Zauważmy, że nic nie wskazuje tu na to, że jeden osobnik usiłuje powtórzyć zachowanie innego, a jedynie powtarzana $\mathrm{w}$ określonych sytuacjach interakcja społeczna prowadzi do powstania sygnału komunikacyjnego". Inną formą wyróżnianą przez Tomasello jest tzw. ekspozycja bodźca, czyli sytuacja, w której zwierzę po prostu wskutek bytowania razem z innymi członkami stada natrafia na określone miejsca czy przedmioty, wzmacniając określone skojarzenia (np. uczy się, że odwracanie kłody często prowadzi do odnalezienia pożywnych jaj i larw owadów).

4 Bardzo szczegółowy opis zachowań dzieci z niewykształconą teorią umysłu zob. Kozłowski 2007. 
pojęcia Ja. Brak tych elementów ściśle wiąże się zatem z niemożnością wytworzenia jakiegokolwiek trwale uwewnętrznionego systemu normatywnego. Norma społeczna zasadza się wszak na rozumieniu:

a) sytuacji wyabstrahowanej, niejako jej typu idealnego, do którego przyrównywana jest sytuacja „zastana” i dopiero po uwzględnieniu rozbieżności (typ idealny versus rzeczywistość) obrane zostaje adekwatne działanie;

b) oczekiwań innych osób względem nas samych; istota kultury w takim sensie, $\mathrm{w}$ jakim formułuje go psychologia ewolucyjna, to w głównej mierze świadomość istnienia określonych oczekiwań względem naszej osoby.

Typowe cechy funkcjonowania bez teorii umysłu to, prócz uczenia na zasadach behawiorystycznej tresury, koncentracji na tu i teraz oraz niemożności tworzenia szerszych abstrakcji:

a) niezwracanie uwagi na cechy charakteru, zarówno swoje, jak i partnera;

b) nietrwałość i periodyczność interakcji;

c) zorientowanie na materialny cel;

d) brak empatii;

e) brak umiejętności planowania;

f) brak możliwości skutecznej manipulacji partnerem (inteligencja makiaweliczna).

Wnioski płynące $z$ obserwacji prowadzonych przeze mnie $\mathrm{w}$ kilku przedszkolach dają się przedstawić $\mathrm{w}$ formie następującej tabeli (szerzej zob. Kozłowski 2007):

\begin{tabular}{|c|c|c|}
\hline Zdolności psychospołeczne & Trzylatki & Sześciolatki \\
\hline $\begin{array}{l}\text { Mechanizm regulujący } \\
\text { orientację w otoczeniu }\end{array}$ & $\begin{array}{l}\text { świadomość (wychwytywanie at- } \\
\text { raktorów uwagi) }\end{array}$ & $\begin{array}{l}\text { samoświadomość (nastawienie na } \\
\text { dostrzeganie relacji występują- } \\
\text { cych między zjawiskami) }\end{array}$ \\
\hline $\begin{array}{l}\text { Wykorzystywana pa- } \\
\text { mięć }\end{array}$ & $\begin{array}{l}\text { krótkotrwała (wąska perspektywa } \\
\text { czasowa przestrzenna: tu i teraz) }\end{array}$ & $\begin{array}{l}\text { autobiograficzna (szeroka per- } \\
\text { spektywa czasowa i przestrzenna) }\end{array}$ \\
\hline $\begin{array}{l}\text { Mechanizm regulujący } \\
\text { działanie }\end{array}$ & $\begin{array}{l}\text { zewnętrzne warunkowanie } \\
\text { (strach, nawyk) }\end{array}$ & $\begin{array}{l}\text { uwewnętrzniona norma (wstyd/ } \\
\text { poczucie winy, namysł) }\end{array}$ \\
\hline Organizacja społeczna & $\begin{array}{l}\text { brak (bawią się wszyscy, choć } \\
\text { osobno) }\end{array}$ & jest (podział na role) \\
\hline Autorefleksja & $\begin{array}{l}\text { brak (skoncentrowanie na odbio- } \\
\text { rze bodźców) }\end{array}$ & $\begin{array}{l}\text { jest (odwoływanie do wcześniej- } \\
\text { szych doświadczeń) }\end{array}$ \\
\hline Rola emocji & nadrzędna & regulowana przez normę \\
\hline $\begin{array}{l}\text { Źródła wiedzy i nastawie- } \\
\text { nie względem otoczenia }\end{array}$ & egocentryzm & $\begin{array}{l}\text { uwzględnianie perspektywy Inne- } \\
\text { go }\end{array}$ \\
\hline Podatność na manipulację & ogromna & $\begin{array}{l}\text { relatywnie zmniejszona przez } \\
\text { obecność teorii umysłu }\end{array}$ \\
\hline Rola kontekstu & marginalna & zasadnicza \\
\hline Rola zabawy & autostymulacja & integracja \\
\hline Zdolności kulturotwórcze & żadne & wysokie \\
\hline
\end{tabular}


Podział ten bardzo dobrze opisuje rozbieżności, jakie pojawiają się nie tylko między dziećmi w określonym wieku, ale także różnice między uczestnikami kultury (kolumna prawa) a konsumentami (kolumna lewa).

Z punktu widzenia rozważań na temat istoty dziedziczenia protokulturowego ważne jest, by zdać sobie sprawę, że z tej perspektywy teoria umysłu jest jednocześnie warunkiem sine qua non „wystartowania” procesów kulturowych. Dzieci pozbawione teorii umysłu funkcjonują w środowisku społecznym według prawideł typowych dla protokultur, systemów powszechnych wśród niektórych grup naczelnych, opisywanych wcześniej. Ich wirtuozeria jest oczywiście w tym względzie daleko większa; dzieci, nie ulega to najmniejszej wątpliwości, $z$ pewnością potrafią więcej niż szympansy, jednak mechanizm nabywania wielu umiejętności pozostaje ten sam: jest to wyuczenie zachowań bez rozumienia intencji innego, wzmocnione dzięki odpowiednim stanom emocjonalnym, wywołanym nagrodą bądź karą. Ale nie oznacza to, że elementy dziedziczenia protokulturowego - w przypadku Homo sapiens sapiens - występują jedynie wśród trzylatków. Bardzo prawdopodobne, że protokultura przejawia się w różych formach i na innych płaszczyznach życia normalnych, dorosłych członków społeczeństwa, niepozbawionych poprawnie funkcjonującej teorii umysłu.

Uważam, że obszarem sprzyjającym powstawaniu i utrzymywaniu się praktyk protokulturowych jest wytwór społeczeństwa zdominowanego przez współczesne media i paradygmat konsumpcji: popkultura.

\section{EMOCJE, ICH MIEJSCE I ROLA W POPPRZEMYŚLE}

Wiele przemawia za tym, by za podstawę przemysłu popkultury uznać emocje konsumentów. Na skojarzeniach emocjonalnych bazuje bowiem filozofia takich pojęć jak logo, marka czy infotainment - nurt programowy obecny w dzisiejszych mediach (zob. Legutko, Rodziewicz 2007), które dla popkultury mają znaczenie fundamentalne.

Logo, czyli znak towarowy, nie od zawsze miało rację bytu. Dawniej, gdy siły wytwórcze dalekie były od poziomu, jaki osiągany jest dziś prawie we wszystkich sektorach rynku, z mediami włącznie, logo było niepotrzebne. Konsument, wybierając się do sklepu, kupował chleb, mąkę i inne towary bez zastanawiania się nad tym, jaki i czyj jest to produkt. Producentów było tak niewielu, lub tak niewiele towaru byli oni w stanie wyprodukować, że po prostu nie wchodzili sobie w drogę, wobec czego klient nie musiał zaprzątać sobie głowy spamiętywaniem dostawców.

Stopniowa zmiana zachodziła w miarę postępu mechanizacji i rozwoju przemysłu. Moce wytwórcze rosły i rynek powoli zalewany był coraz większą ilo- 
ścią dóbr. W pewnym momencie okazało się, że mąki, tak samo jak chleba, mleka, płótna czy gwoździ, może być kilka rodzajów, przy czym każdy producent zamierza zarobić tak samo dobrze. Można zaryzykować twierdzenie, że do tej chwili koncepcja homo oeconomicus autorstwa Adama Smitha obowiązywała: człowiek po prostu kupował to, co potrzebne, postępując z grubsza racjonalnie. Gdy zaś nastała klęska urodzaju, należało odwołać się do argumentów innych niż racjonalność i wymyślić logo, które pod kilkoma warstwami farbki i złotka przemycać będzie cały zestaw znaczeń. Benjamin Barber (2008) ogół tych pozamerytorycznych argumentów ochrzcił mianem etyki konsumenckiej, która nakazuje bazować na prostych, nie do końca uświadamianych skojarzeniach i wybierać te towary (a w przypadku mediów - te programy), które obiecują największą satysfakcję. Zorientowanie na emocje konsumenckie i argumentację pozaracjonalną staje się tym samym racją bytu współczesnych producentów. Ich nadzieja to malejący namysł konsumenta nad swymi potrzebami i drogami ich zaspokojenia, mniejsza refleksyjność bowiem znacznie zwiększa niepowstrzymane nabywanie, świadomy namysł może okazać się przeszkodą.

O tym, że taka strategia odnosi skutki, może świadczyć to, iż trudno zakładać, by w obecnych czasach uczestnictwo $\mathrm{w}$ popkulturze $\mathrm{w}$ całości było rezultatem zamierzonego procesu. Może to nie dotyczyć większości przypadków. Z badań Williama Wilkiego (1994; por. D’Alessandro 2001) wynika, że rola planowania $\mathrm{w}$ podejmowaniu decyzji konsumenckich jest przesunięta na drugi plan. Wilkie wyodrębnia cztery zasadnicze typy nabywania i konsumpcji:

a) specjalnie zaplanowane;

b) zaplanowane ogólnie;

c) zastępcze;

d) niezaplanowane.

Pierwsze zostało zaplanowane jeszcze nim kupujący wszedł do sklepu. Druga kategoria to ogólne plany, nad którymi konsument rzadko się zastanawia. Zaliczamy tutaj postanowienia w rodzaju „a może by tak kiedyś kupić sobie...". Plany takie często ciągną się miesiącami, czy nawet latami, nie mogąc doczekać się finału. Kolejna kategoria to zakupy zastępcze pojawiające się, gdy zamiast planowanego towaru decydujemy się na inny. Zakupy niezaplanowane $z$ kolei mają miejsce, jeżeli konsument nie zamierzał $\mathrm{w}$ ogóle kupować konkretnej rzeczy, nawet gdy już wszedł do sklepu.

W myśl koncepcji homo oeconomicus ludzie rozważnie gospodarują swoimi zasobami i każdy wydatek (a przynajmniej ich większość) starannie planują. Badania Wilkiego potwierdzają jednak, że zakupy zaplanowane to tylko jedna trzecia wszystkich przypadków. Aż $67 \%$ to przypadki pozostałe, z czego aż $52 \%$ to zakupy niezaplanowane. W typologii Wilkiego, wśród zakupów niezaplanowanych na szczególną uwagę zasługuje zakup impulsywny. Polega on na wystąpieniu silnego pragnienia nabycia jakiegoś towaru. Są to zachowania, których mechanizm zbliżony jest do prostego, behawioralnego schematu bodziec-reakcja. Zakupy impulsywne stanowią odpowiedź konsumenta na obec- 
ność określonej, wyjątkowo atrakcyjnej oferty, podobnie jak określona reakcja organizmu jest odpowiedzią ustroju na bodźce płynące z zewnątrz. Nie ma podstaw, by sądzić, że w kontakcie $z$ ofertą mediów ludzie postępują w sposób daleko bardziej refleksyjny.

Nasze konsumenckie wybory pozbawione są komponentów, które Benjamin Barber uznałby za typowe dla umysłu „dorosłego”. Okazuje się, że jeżeli wybór jest trudny, nie lubimy zaprzątać sobie głowy poszukiwaniem informacji pewnej i sprawdzonej, co — zwłaszcza w przypadku znacznego wydatku powinno być sprawą priorytetową. Badania Wilkiego i Petera Dicksona (1989, s. 104) przeprowadzone na dużej grupie Amerykanów wskazują, że osoby badane mają nadzwyczajną skłonność do zasięgania rady ze źródeł nie do końca rzetelnych, stronniczych (sprzedawca produktu - 40\%, reklama prasowa $13 \%$ ) lub mało kompetentnych (rodzina i znajomi $-13 \%$ ). Na rozmowę $z$ fachowcem decyduje się zaledwie 5\%. Teoretycznie trudno się temu dziwić zasób informacji niezbędnych do dokonania najlepszego wyboru często przekracza możliwości umysłu. Samodzielne wybranie najlepszego aparatu cyfrowego w określonym przedziale cenowym wymaga znacznej biegłości w całej materii. Potwierdza to jednakże tezę, że konsumenci wolą po prostu zdać się na swoje wrażenie (pozytywne emocje wywołane reklamą, sloganem) lub na opinię kogoś innego (jednak w przeważającej liczbie nie są to fachowcy). Zarówno w jednym, jak i drugim przypadku konsument pozwala zatem, by decyzja została podjęta bez uwzględnienia racjonalnych, merytorycznych kryteriów. Jego główne motywy to emocje, natomiast informacje, jakimi dysponuje, są nierzetelne, skrótowe.

Oczywiście nie wyczerpuje to zagadnień związanych z problemem nieracjonalności wyborów konsumenckich. Warto w tym kontekście zwrócić uwagę na badania Josepha Alby, Wesleya Hutchinsona i Johna Lyncha (1990), których rezultaty wskazywały na przemożną tendencję do myślenia na zasadzie przypisywanym poszczególnym produktom etykietek, nawet jeśli ich funkcja w ostatecznym rozrachunku okazywała się dezinformująca. W eksperymencie grupie badanych osób przedstawiano dwa produkty, konkretnie kamery. Pierwszą z nich opatrzono etykietą „zaawansowana technologicznie”, druga była zaś była „łatwa w użyciu”. Szczegółowy opis kamer sugerował jednak, że kamera B jest nie tylko łatwa w użyciu, ale i również pod każdym względem lepsza od kamery A. Okazuje się jednak, że informacje te $z$ biegiem czasu miały znacznie mniejszą wartość niż przypisane kamerom etykietki. Bez względu na to, czy kamerę B prezentowano badanym zaraz po kamerze A, czy dwa dni po niej, badani przyznawali, że jest ona łatwiejsza w obsłudze. Jednak gdy pytano o jej przewagę techniczną, sprawa zaczynała się komplikować. Etykieta „zaawansowanej technologicznie" kamery najwyraźniej mocno zakorzeniła się w pamięci badanych. $\mathrm{Ci}$, którzy produkt $\mathrm{B}$ oglądali zaraz po wariancie $\mathrm{A}$, stwierdzali, że jest on lepsza już tylko w $68 \%$ przypadków. W miarę zwiększania interwału czasowego do dwóch dni, odsetek ten malał nawet do 36\% Dzięki etykietce 
ewidentnie gorszy towar postrzegany był jako lepszy przez blisko dwie trzecie potencjalnych nabywców. $Z$ tego wniosek, że nawet $\mathrm{w}$ pełni poinformowani klienci nie zdają sobie sprawy $z$ reguł stojących za decyzją, która powinna przecież być w pełni suwerenna.

Badania Geralda Gorna (1982) stanowią dobry przykład potwierdzający siłę zwykłego, Pawłowowskiego warunkowania w reklamie. „Towarem” wykorzystanym w eksperymencie były dwa rodzaje piór: beżowe i niebieskie. Ustalono, że oba rodzaje wybierano tak samo często (podobały się $\mathrm{w}$ takim samym stopniu). W drugim etapie doświadczenia pojawił się bodziec modyfikujący: muzyka. Jednym z dwóch emitowanych fragmentów był lubiany motyw z filmu Grease, drugim zaś tradycyjna muzyka indiańska, ogólnie postrzegana jako trudna i bardziej wymagająca. Mając dwa pióra i dwa rodzaje muzyki, Gorn stworzył macierz obejmującą cztery warianty sytuacyjne, w każdym przedstawiając badanym jedno pióro i jedną melodię. Badanym powiedziano, by nie brali pod uwagę barwy pióra, ponieważ agencja reklamowa, zainteresowana jest przede wszystkim doborem odpowiedniej muzyki. Zadaniem badanych było zatem ocenić podkład muzyczny. Na tym kończyła się „jawna” część eksperymentu. Następnie powiedziano, że za udział w całej procedurze badani mogą zabrać jedno pióro. Okazało się, że na ogół wybierano pióro prezentowane na tle muzyki lubianej, niezależnie od koloru. Rzecz jasna, badani nie zdawali sobie sprawy z procesu, który leżał u podstaw takiego zachowania.

\section{ROZKOJARZENIE JAKO STAN PERMANENTNY}

Świadomość, w odróżnieniu od samoświadomości, funkcjonuje na zasadach reflektora wyłapującego ze środowiska wybrane elementy, podczas gdy inne nikną $\mathrm{w}$ mroku nieświadomości. Istnieją badania, które pozwalają przypuszczać, że przynajmniej do pewnego stopnia konsument zarzuca analizę rzeczywistości typową dla umysłów samoświadomych i obiera strategię „reflektorową". Dzieje się tak podczas korzystania $z$ wielu źródeł informacji naraz. Ukuto nawet termin oddający specyfikę pracy umysłu ludzkiego w dobie mediów XXI wieku: multitasking, czyli wielozadaniowość lub współużytkowanie (zob. Wojak 2008). Z badań Pentor Research przeprowadzonych na zlecenie Tequila/Polska w 2007 r. wynika, że najczęściej stosowane są następujące kombinacje mediów: $36 \%$;

- rozmawianie przez telefon $\mathrm{z}$ równoczesnym oglądaniem telewizji —

- oglądanie telewizji oraz czytanie prasy - 35\%;

- czytanie prasy połączone ze słuchaniem audycji radiowych $-27 \%$;

- oglądanie telewizji połączone $z$ wysyłaniem SMS-ów - 25\%.

Co ciekawe, nie jest to wyłącznie domena młodych. Multitasking funkcjonuje $\mathrm{w}$ niemal wszystkich grupach wiekowych. Praktyki takie mają miejsce wśród $60 \%$ ludzi w przedziale wiekowym od 15 do 29 lat i 36\% powyżej 60 lat. 
Multitasking zaczyna stawać się dominującą strategią funkcjonowania w rzeczywistości multimediów, co pociąga za sobą określone konsekwencje. Ponieważ nie jesteśmy $\mathrm{w}$ stanie poświęcać się kilku zadaniom jednocześnie $z$ taką samą uwagą, pozostaje ona rozproszona, co skutkuje gorszym rozumieniem, zapamiętywaniem i przypominaniem. Skutki takie potęgują się, gdy odbierane treści pozostają ze sobą niezwiązane znaczeniowo (Bergen, Grimes, Potter 2005). Ludzie, którym przedstawia się zbliżoną liczbę informacji różnych treściowo, radzą sobie $z$ ich przetworzeniem daleko gorzej aniżeli ci, którzy mieli możliwość śledzenia jedynie informacji powiązanych. Wnioski są jednoznaczne: wielość strzępków informacji bardzo utrudnia ich zrozumienie. Biorąc pod uwagę to, że wedle przytaczanych danych multitasking staje się dominującą strategią przetwarzania danych, możemy stwierdzić, że ustawicznym stanem umysłu, typowym dla późnonowoczesnego społeczeństwa zachodniego staje się niekończące się rozdrabnianie uwagi i uboższe rozumienie treści.

\section{POPKULTURA A POWSTAWANIE I TRWANIE GRUP SPOŁECZNYCH}

Cechą typową dla grup trzylatków jest brak struktury społecznej. Nieumiejętność przyjęcia perspektywy Innego powoduje, że niemożliwe jest przyjęcie jakiejkolwiek roli. Rola społeczna obejmuje wszak obszerną wiedzę dotyczącą zachowania względem określonej grupy ludzi. Brak świadomości istnienia takich oczekiwań przekreśla jednocześnie adekwatne stosowanie repertuaru ról, w związku z czym osoby bez teorii umysłu nie przyjmują świadomie żadnej roli społecznej. Zabawy dzieci bez teorii umysłu nie mają określonego porządku, dzieci bawią się ze sobą, choć osobno. Zabawa w grupie po prostu nie występuje, role nie są przypisywane ani nie są egzekwowane, nie pojawiają się grupowe inicjatywy czy wspólne cele. $Z$ zupełnie inną sytuacją mamy do czynienia $w$ grupach dzieci starszych, w których zabawa $z$ podziałem na role stanowi standard. Bardzo wyraźnie zaznaczają się wewnętrzne podziały (chłopcy contra dziewczynki, grupy najlepszych kolegów, najlepszych koleżanek, pary, triady itp.). Grupy potrafią również skoncentrować swoje działanie wokół wspólnego celu (na przykład presja wywierana na opiekunki w celu wyjścia na podwórko itp.).

Kontynuując nasze rozważania należy zadać pytanie, w jakim stopniu utworzenie i funkcjonowanie grupy społecznej oraz spójnego systemu wartości możliwe jest na płaszczyźnie popkultury? Czym byłaby grupa stworzona na jej bazie? Za przykład ciekawych inicjatyw mogą służyć społeczności fanowskie, tzw. fandomy, czyli grupy wielbicieli jakiegoś produktu (filmu, fabuły, grupy, postaci czy innego nurtu zjawisk pop). Nie ulega wątpliwości, że z punktu widzenia socjologii i antropologii całości te spełniają wszystkie kryteria konieczne do uznania ich za pełnoprawne grupy społeczne: mają konkretną strukturę, 
obowiązujące normy i wartości, kody wykorzystywane do komunikacji, rytuały towarzyszące spotkaniom, przynależność do grupy wyraża się również na płaszczyźnie tożsamości: członkowie identyfikują się z nią, jest ona ich częścią. Społeczności fanowskie narosłe wokół fenomenu Gwiezdnych wojen, Władcy Pierścieni, Harry'ego Pottera itd. stanowią niebywale bogate źródło danych na temat zasad funkcjonowania takich grup. Wyróżnia je także bogata twórczość — fani przedstawiają na forum alternatywne scenariusze swojego autorstwa, niekiedy nawet tworzą grupy wyznaniowe, jak w przypadku religii Jedi (o siedemdziesięciu tysiącach wyznawców doniósł australijski spis ludności z 2002 r.). Pytanie jednak, czy w dalszym ciągu mamy do czynienia ze zdarzeniami dziejącymi się w obrębie popkultury?

Społeczność fanowska nie jest niczym innym jak kółko zainteresowań, zgromadzenie hobbystów, którzy stanowią raczej wyjątek aniżeli regułę. Czynią oni $z$ produktu popkultury swoisty fetysz, który interpretowany i analizowany jest znacznie głębiej, aniżeli wymaga tego od nich producent i cały rozrywkowy przemysł. W zamyśle producenta leży przede wszystkim nabycie określonego dobra, nie zaś jego - odpowiednia lub nie - interpretacja. Zdecydowana większość konsumentów nie oddaje się tego rodzaju aktywności i przyswaja ofertę w sposób mniej fanatyczny. Społeczność fanowska, choć swoje główne motywy czerpie z popkultury, funkcjonuje poza jej głównym nurtem. Nie jest to społeczność złożona z konsumentów, ale nieomal z „wiernych”, dla których wybrany motyw stanowi jedynie płaszczyznę i podstawę komunikacji z innymi. W grupach tych dany fetysz jest dyskutowany, dekonstruowany, reinterpretowany, pojawia się nawet mnogość określonych nurtów, wszystko to jednak stanowi zjawisko wyjątkowe, niszowe, do którego zwykły konsument w zasadzie nie ma wstępu. Zwykły uczestnik popkultury pozostaje jedynie biernym fanem, nie zaś aktywnym twórcą. Dotychczas nie pojawiło się nic takiego jak niemiecka szkoła interpretacji twórczości Britney Spears, francuski kierunek w śledzeniu serialu Prison Break czy polski paradygmat myśli Obi Wana Kenobiego. Popkultura nie jest zainteresowana tego rodzaju aktywnością $z$ prostego powodu: jest to nieopłacalne. Z perspektywy twórców popoferty najbardziej pożądana postawa to konsument otwarty na mnogość treści i możliwie bezkrytyczny. Najlepsze treści z kolei to te, które docierać będą do grona jak największego, a nie do ekskluzywnej grupki maniaków.

Sądzę, że najlepszy przykład „wspólnot”, które powstają w łonie popkultury, a więc przeznaczonych dla milionowego grona odbiorców, to portale społecznościowe oraz zjawisko Web 2.0. Znaczna moda na tego rodzaju ofertę stanowi zjawisko masowe, spełnia zatem założenia produktu nurtu pop. Portale te umożliwiają nawiązanie kontaktu $z$ wybranym użytkownikiem, kompletowanie grupy znajomych, autoprezentację i bieżące informowanie o tym, co akurat dzieje się u konkretnego użytkownika, prowadzenie dyskusji na wybrany temat itd. Ale zjawisko Web 2.0 to nie tylko portale społecznościowe, to cała gałąź usług i kierunek rozwoju mediów. Pierwotnie Web 2.0 oznaczało nowy typ 
serwera zaprojektowanego na początku XXI wieku, a sens jego nowości zasadzał się na treściach tworzonych nie tylko przez administratora danej witryny, ale także - a może przede wszystkim - przez jej użytkowników. Redakcje takich serwerów (np. popularnego Plotka, Pudelka czy Kozaczka) jawnie zachęcają internautów do przesyłania wiadomości oraz żywego komentowania każdego doniesienia. Elementy takiego podejścia są dostrzegalne zresztą nie tylko $\mathrm{w}$ internecie. $\mathrm{Z}$ powodzeniem widoczne są bowiem również $\mathrm{w}$ telewizji czy radiu, za sprawą rosnącej roli odbiorcy. Telewidzowie i słuchacze coraz częściej proszeni są o swoje opinie - te ukazują się w postaci przytaczanych SMS-ów i maili. Odbiorcy często stają się bohaterami popularnych programów. Goszczą w konkursach, programach w rodzaju talk-show, wiadomości od nich mogą przyciągnąć reporterów serwisu informacyjnego, a niektórzy nawet pojawiają się $\mathrm{w}$ serialach. Ukoronowaniem tego trendu - postawienia W centrum zainteresowania człowieka pospolitego - jest zjawisko celebryty, czyli bożyszcza tłumów, cenionego za zwyczajność, pospolitość, jednego z nas (Godzic 2007). Tendencję tę dobitnie przedstawia Andrew Keen (2007), nazywa ją „kultem amatora”. Kult ten dostrzegalny jest w szczególności właśnie w treściach portali społecznościowych, gdzie w centrum znajduje się człowiek przeciętny, każdy z nas.

W przedmowie do Kultu amatora Kazimierz Krzysztofek stwierdza, że obszar Web 2.0 może wykazać się znacznym potencjałem kulturotwórczym. Stwierdza, że oto wkraczamy w nowy cykl kultury, trudny do zdefiniowania, choć nawiązujący do najwcześniejszych jej stadiów - kultury oralnej. W sieci twierdzi Krzysztofek (2007, s. 20) - zacierają się już granicę między odbiorcą komunikatu a jego nadawcą, dzięki czemu mamy tam do czynienia z "czystą komunikacją", a miliardy SMS-ów i e-maili wysyłanych każdego dnia każą wierzyć, że na naszych oczach powstaje jakaś forma inteligencji kolektywnej, nowa kultura, która wymaga nowej antropologii. Swój optymistyczny wywód socjolog podsumowuje twierdzeniem, że ,jest to raczej kultura działania społecznego niż instytucji”. Osobiście nie podzielam entuzjazmu Krzysztofka. Odnoszę natomiast wrażenie, że postulat narodzin kul tu ry bez instytucji przekreśla całkowicie sens wywodu. $Z$ punktu widzenia psychologii ewolucyjnej kultura bez instytucji po prostu nie istnieje. To, co opisuje Krzysztofek, w najlepszym razie jest pewnym zwyczajem, sposobem komunikowania się, który trudno nawet uznać za normę, a czymże jest kultura pozbawiona norm? Procesy spontanicznego komunikowania wynikają ze specyfiki narzędzi, które oddano ludziom $\mathrm{w}$ posiadanie. Internauta po prostu używa komputera, wypowiada się na forach, kreśli tu i tam kilka zdań, ale czy naprawdę wystarcza to, by mówić o „swoistej rearchaizacji spontanicznej komunikacji, wtórnej oralności"? Proces ten niekoniecznie postrzegany może być jako triumfalne zatoczenie koła, ale po prostu jako regres. Pamiętajmy, że powrót do kultury przedpiśmiennej oznacza po części upadek cywilizacji. 
Zdaniem Keena (2007), elementem, który w dużej mierze przyczynia się do wypaczenia istoty procesów kulturotwórczych, jest panująca $\mathrm{w}$ internecie anonimowość. Świat Web 2.0 funkcjonuje bez podstawowego wymogu leżącego u podstaw jakiegokolwiek tworu społecznego - z a u fan ia. Jest ono, jak wiadomo, konieczne, by wyłoniła się większa, bardziej trwała wspólnotowa całość (zob. Sztompka 2007). Jeżeli uczestnicy interakcji ukrywają się za nickiem lub awatarem, jeżeli nie ma pewności, że rozmówca jest tym, za kogo się podaje, to sens interakcji stoi pod znakiem zapytania. Ulotność i efemeryczność tego typu relacji przekreśla możliwość tworzenia bardziej trwałych więzi i stosunków, a tym samym wyłonienie się czegoś, co można by określić mianem „tradycji internetu”. Taki stan rzeczy przewidzieli zresztą tacy klasycy jak David Riesman (1971) czy Jeremy Rifkin (2003), pisząc o samotnym tłumie i jednostkach wykorzenionych $z$ tradycji. Niewykluczone, że dzisiejsze ponowoczesne społeczeństwa, powracając do kultury oralnej, możliwej dzięki zaawansowanej technologii, zaprzestają powoli tworzyć dziedzictwo, które ma szansę stać się elementem wspólnej tradycji? Być może ludzie z czasem przestają już czuć więź z tradycją, a $z$ drugiej strony tradycja staje się coraz mniej namacalna i ma coraz mniejsze znaczenie? Być może wracamy do etapu, na którym egzystencja społeczeństwa nie jest już rozciągnięta w czasie, ale ograniczona do wiecznej teraźniejszości?

Grupy, jakie wyłaniały się jako rezultat działania na polu Web 2.0, w krótkim czasie okazywały się bytami pozornymi, bez większego znaczenia. Po śmierci Jana Pawła II zaroiło się w internecie od prywatnych zwierzeń milionów osób związanych w jakiś sposób z osobą papieża. Atmosfera, która zapanowała wówczas we wszystkich mediach, ogólnonarodowe katharsis, mocno przyczyniła się do postawienia bardzo odważnej tezy, że oto jesteśmy świadkami narodzin „pokolenia JP2”. Gdyby byt taki faktycznie się narodził, doczekałby się swojej strony internetowej, kanału na YouTube, zainicjował kilka konferencji, ustrukturyzował się $\mathrm{w}$ jakiś sposób - moglibyśmy przyjąć, że na łonie popkultury, w końcu papież również był swoistą ikoną popświata, zapośredniczoną przez media masowego przekazu, doszło do powstania prawdziwej, przy tym ogromnej, grupy społecznej. Pokolenie JP2 okazało się jednak bardzo nietrwałe, jeśli w ogóle można mówić, że kiedykolwiek powstało i trwało. Czy nie było ono raczej sumą indywidualnych przeżyć, zbliżonych emocji, wyrażanych w tym samym czasie, w przestrzennej bliskości? Wszelkie byty ponadjednostkowe, jakie stara się tworzyć popkultura, mają bardzo ulotną naturę, na ogół trwają tak długo, jak długo media są nimi zainteresowane, przy czym istnieją jedynie na okładkach czasopism i w telewizyjnych spotach. Jest co najmniej wątpliwe, że miliony ludzi ochrzczonych mianem pokolenia JP2 faktycznie poczuły się spadkobiercami nauk Karola Wojtyły. Nie inaczej jest z portalami społecznościowymi. Ich olbrzymia popularność, czy to Naszej-Klasy, MySpace czy wreszcie Facebooka, wyznaczana jest nie przez prawidła tworzenia i trwania grup społecznych, ale przez reguły przemijania mód. 


\section{CHARAKTER, OSOBOWOŚĆ, TRADYCJA}

Kolejny aspekt, któremu należy poświęcić uwagę w kontekście rozważań nad elementami transmisji protokulturowej, to rola jednostki i sposób funkcjonowania jej umysłu. Mówiliśmy, że fundamentem funkcjonowania popkultury są emocje, które potrafi ona wzbudzać w swoich konsumentach i to one w ogromnym stopniu stają się przyczyną konkretnych zachowań. Założenie to doskonale pasuje do teorii psychoewolucyjnych wyjaśniających sposób funkcjonowania świadomości. W koncepcjach takich badaczy jak Gerald Edelman, Donald Griffin, Euan Macphail czy wreszcie Antonio Damasio rola świadomości polega na swoistym kolekcjonowaniu bodźców ze środowiska i adekwatnym reagowaniu na nie. Jest ona „wiedzą, że świat jest”, w odróżnieniu od samoświadomości, które "jest wiedzą, że się jest” (zob. Macphail 2002), które pozostają „jedynie” świadome. Co prawda, zdają sobie sprawę z tego, że istnieją konkretne bodźce, jednak nie wiedzą nic o ich przyczynach, nie potrafią powiązać zdarzeń $\mathrm{w}$ szerszy kontekst, a ich horyzont poznania nie wykracza poza wąską przestrzeń i krótki czas, co jest typowe dla kluczowej roli, jaką odgrywa w ich przypadku pamięć krótkotrwała.

W przypadku podmiotów samoświadomych sytuacja wygląda już zupełnie inaczej - potrafią one dostrzegać złożone relacje między obiektami i procesami, poza tym $w$ tym złożonym świecie zdolne są umiejscowić same siebie, są zatem świadome miejsca, które zajmują w ogólnym porządku. Potrafią wybiegać myślą poza czas i przestrzeń, rozważać to, co było lub będzie, nie ograniczają się zatem do biernych reakcji na bodźce, ale starają się rozumieć i przewidywać rzeczywistość.

Dychotomia ta doskonale pasuje do niektórych koncepcji budowanych na gruncie antropologii i psychologii społecznej. Chyba najlepszym przykładem jest tutaj koncepcja człowieka wewnątrzsterownego i zewnątrzsterownego w połowie XX wieku sformułowana przez Davida Riesmana, który wskazywał na rolę:

- charakteru, czyli zespołu immanentnych cech jednostki, uwewnętrznionych norm itp., które wykorzystuje ona, niczym busolę, w codziennym życiu oraz

— osobowości, konstruktu społecznego stanowiącego coś na kształt fasady, maski przywdziewanej w zależności od sytuacji, która stanowi zorientowany na odgłosy z zewnątrz „radar”.

Pierwiastek charakteru typowy jest dla ludzi wewnątrzsterownych, osobowość zaś - dla tych zewnątrzsterownych. Zdaniem Riesmana, w połowie wieku XX Stany Zjednoczone (a za nimi Europa) podążyły w stronę zewnątrzsterowności, za sprawą której życie społeczne stało się bardziej powierzchowne, polegające na grze pozorów, znamiennym keep smiling, a najczęściej spotykane przelotne kontakty nie angażują na ogół całej jednostki, lecz jedynie jeden jej wybrany aspekt. Śladami Riesmana podążyło wielu innych badaczy, 
powstały koncepcje jaźni postmodernistycznej, jaźni proteuszowej i inne, wskazujące na pokawałkowanie i powierzchowność wielu aspektów życia ludzkiego (zob. Lifton 1993). Brak spójnego rdzenia czy coraz mniejsza rola wspólnego dziedzictwa, tradycji, powodują, że ludzie przekształcają się w ów „samotny tłum", którego członkowie gonią za własnym, a nie wspólnym interesem.

Co ciekawe, koncepcje te niespodziewanie dobrze pasują do wniosków pojawiających się na gruncie nauk ewolucyjnych, które starają się opisać prawidła rządzące zachowaniem większych grup zwierząt, nie wykorzystujących tak złożonych całości jak samoświadomość, pamięć zbiorowa, kultura czy tradycja. Nie oznacza to oczywiście, że ludzie zniżają się umysłowo do ich poziomu, lecz jedynie, że dzielą z nimi niektóre mechanizmy funkcjonowania. Samoświadomość i inne „dobrodziejstwa” naszego gatunku wcale nie są bowiem do takiego funkcjonowania niezbędne. Zwierzęta pod wieloma względami również pozostają zewnątrzsterowne. Są one raczej więźniami chwili bieżącej i to na niej koncentrują wszystkie swe zabiegi. To dana chwila wpływa na nie i warunkuje ich działania. Zwierzęta - przynajmniej te, u których nie podejrzewa się istnienia samoświadomości - niczego nie planują, ich zachowania nie wskazują na istnienie pamięci długotrwałej, ich działania pozbawione są szerszego kontekstu i zawsze odnoszą się do chwili obecnej i konkretnego miejsca. Zwierzęta te zainteresowane są przede wszystkim zaspokajaniem indywidualnych potrzeb. Nie przymierzając, jest to charakterystyka ludzi zewnątrzsterownych, którą Riesman odmalował w Samotnym tłumie. Oczywiście nie oznacza to, że ludzie, nawet ci najbardziej zewnątrzsterowni, niczego nie planują, nie uświadamiają sobie konsekwencji swych czynów itd. Ich plany obejmować mogą jednak znacznie węższy zakres czasowy niż zaledwie kilka dekad wcześniej wśród osób wewnątrzsterownych. Ich plany nie obejmują miesięcy i lat, najwyżej dni, tygodnie i to na nich się koncentrują.

O niemożności czynienia dalszych planów przekonująco mówi Richard Sennett w Korozji charakteru (2006; zob. też 2009a i 2009b), wskazując na niekorzystne warunki rynkowe, wypaczające rozumienie życia ludzkiego jako spójnego procesu. Wymóg ciągłego przekwalifikowywania się, częstego zmieniania miejsca zatrudnienia, nierzadko pociągający za sobą konieczność zmiany miejsca zamieszkania, miasta, a ostatnio nawet kraju, powoduje, że ludzie coraz słabiej zakorzeniają się gdziekolwiek i coraz rzadziej czują się spadkobiercami czegoś, z czym mogliby się utożsamiać. Czy oznacza to, że ludzie tak naprawdę chcieliby z takim stanem rzeczy coś zrobić, jednak nie jest im to dane? Niewykluczone. Niewykluczone również, że mamy tu do czynienia z błędnym kołem: nie czujemy się zakorzenieni, ale też nie wymaga się tego od nas.

Czy w związku z tym możliwa jest w świecie popkultury jakaś tradycja? Czy popkultura ma szansę stać się elementem zbiorowego dziedzictwa? Rola tradycji wydaje się coraz mniejsza, zwiększa się z kolei rola komponentu zabawowego, co może być skorelowane z upowszechnieniem się postawy „zdziecinnienia". Obawy te dobrze zarysowuje Jeremy Rifkin w pracy Wiek dostępu 
(2003, s. 62): „Wzrost znaczenia idei w sferze komercyjnej wywołuje mieszane uczucia. Jeśli ludzka myśl staje się tak ważnym towarem, to co stanie się z ideami równie ważnymi, ale nieatrakcyjnymi komercyjnie? Czy będzie miejsce dla niekomercyjnych podglądów, opinii, pojęć i koncepcji w cywilizacji, która opiera życie człowieka tylko na ideach ze sfery komercyjnej? Jeśli wszelkie idee zostaną zawłaszczone w postaci własności intelektualnej przez megakorporacje, jaki to będzie miało wpływ na społeczeństwo, jego zbiorową świadomość i przyszłość?”. Współbrzmi to z tezami Zygmunta Baumana (2007, s. 91-106) wspominającego o „kulturze zapomnienia, która w świecie konsumpcji zastępuję kulturę akumulacji wiedzy". Ale czy w związku z tym kulturę, która nie pamięta i nie akumuluje, $\mathrm{w}$ dalszym ciągu można nazywać kulturą?

\section{CZY KONSUMENT TO DUŻE DZIECKO?}

Nurt krytyczny rozważań na temat rozwoju popkultury często odwołuje się do argumentu zdziecinnienia konsumenta. Na tym gruncie bez trudu można spotkać wyraźne głosy, choćby Neila Postmana, a także wspomnianych Zygmunta Baumana czy Benjamina Barbera, który te tendencje najpełniej opisał $\mathrm{w}$ pracy Skonsumowani. Jak rynek psuje dzieci, infantylizuje dorostych $i$ potyka obywateli. Sęk w tym, że obawy, które uczeni ci formułują na kartach swych książek, nie są jedynie chwytem retorycznym. Argumenty przez nich wysuwane doskonale pokrywają się bowiem $\mathrm{z}$ wnioskami, jakie płyną $\mathrm{z}$ teorii psychoewolucyjnych. Barber (2008, s. 131) wylicza kilkanaście opozycji ilustrujących rozdźwięk między konsumencką dziecięcością a dorosłością:

1) impuls-rozwaga;

2) uczucie-rozum;

3) pewność-niepewność;

4) dogmatyzm-wątpliwość;

5) zabawa-praca;

6) obrazy-słowa;

7) wyobrażenia-idee;

8) przyjemność-szczęście;

9) natychmiastowa gratyfikacja-długoterminowa satysfakcja;

10) egoizm-altruizm;

11) prywatne-publiczne;

12) narcyzm-uspołecznienie;

13) uprawnienie (prawo)-obowiązek (odpowiedzialność);

14) teraźniejszość-przeszłość i przyszłość;

15) bliskie-dalekie;

16) natychmiastowe-trwałe;

17) fizyczna seksualność-erotyczna miłość;

18) indywidualizm-wspólnota;

19) ignorancja-wiedza. 
Listę tę - uwzględniając dotychczasowe rozważania — można z powodzeniem uzupełnić o następujące opozycje:

20) osobowość-charakter;

21) pamięć krótkotrwała-pamięć autobiograficzna;

22) brak roli jako takiej-wielość zinternalizowanych ról;

23) wstyd i strach-poczucie winy;

24) akontekstualność-zorientowanie na kontekst;

25) skojarzenie i odruch-zachowania normatywne.

Biorąc pod uwagę wskazane opozycje, można dojść do wniosku, że pojęcie zdziecinniałego konsumenta formułowane przez współczesnych obserwatorów popkultury w znacznym stopniu wpisuje się w psychologiczny model dzieciństwa formułowany na gruncie poznawczej psychologii ewolucyjnej. A jeśli tak, to czy można zaryzykować twierdzenie, że w obrębie popkultury mamy do czynienia $z$ funkcjonowaniem społecznym charakterystycznym dla osób z nie do końca rozwiniętym modułem teorii umysłu? Uważam, że co najmniej godna rozważenia jest teza, iż w obrębie popkultury funkcjonują dwie strategie rozprzestrzeniania się określonych wzorców zachowań: wzorzec kulturowy (większa refleksyjność i samoświadomość, przewaga pierwiastka racjonalnego nad emocjonalnym oraz pozostałe świadczące o dojrzałości elementy wyliczanych przez Barbera opozycji) oraz wzorzec protokulturowy (mniej refleksyjności, za to większa emocjonalność, mechanizmy tresury i warunkowania).

\section{PODSUMOWANIE}

Za tezą, że specyfika funkcjonowania popkultury w znacznej mierze opiera się na mechanizmach protokulturowych, przemawiają następujące wnioski:

1. Popkultura jest rzeczywistością, w której główną determinantą zachowania pozostają emocje. Za ich sprawą działania cechują się znacznie mniejszym poziomem racjonalności. Pozostają sprowadzone do prostych, podświadomych zależności i odruchów, z których jednostka w praktyce nie zdaje sobie sprawy. Wiele decyzji konsumenckich podejmowanych jest poza świadomością, a zatem również poza kontekstem społecznym, bez zwracania uwagi na czynniki, które można określić mianem kulturowych. Kultura wszak jest elementem uświadamianym. Poza tym pamiętać musimy, że namysł nie leży w interesie producentów popkultury. Jeżeli więc będą dysponować określonymi narzędziami, których celem będzie wywołanie określonej reakcji — narzędzia te zostaną użyte.

2. Co za tym idzie, kultura wykorzystuje przede wszystkim pobieżną, tymczasową analizę bodźców płynących z otoczenia, skutkiem czego oducza analizy pogłębionej, trwalszej (a przynajmniej jej nie sprzyja). Przyczynia się do wykształcania nawyków, nie sprzyja zaś namysłowi. Nawyk z pewnością nie może być uznany za element kultury. Jest on w pełni wytłumaczalny za pomocą narzędzi psychologii behawioralnej, która analogiczne wyniki uzyskuje bez jakichkolwiek „półśrodków” w postaci oddziaływania społecznego. 
3. Popkultura jakby rezygnuje z niektórych zdolności psychospołecznych, które są nieodłącznym elementem naszego wyposażenia psychologicznego, a także warunkiem koniecznym zainicjowania typowych procesów kulturowych. Przede wszystkim - wydaje się, że popkultura nie angażuje istotnych elementów naszej samoświadomości, takich jak pamięć autobiograficzna, świadomość kontekstu społecznego, skupienie na intencjach partnera interakcji oraz zależnościach łączących go z nami. Interakcje te sprowadzają się bowiem do: a) nabywania i konsumowania - gdy komunikacja jest ograniczona do minimum; b) uczestniczenia w pseudogrupach, takich jak publiczność, w których nie są generowane jakiekolwiek autonomiczne - względem innych zbiorowości - normy internalizowane później przez jednostkę. Innymi słowy, bycie publicznością nie staje się elementem dziedzictwa kulturowego, z którym jednostka się utożsamia. Są to anonimowe zbiorowości, złożone z pojedynczych osób zainteresowanych głównie indywidualnym odbiorem i doświadczaniem.

4. Popkultura upośledza głębokie procesy psychologiczne, które stanowią podstawę funkcjonowania człowieka, zwłaszcza jego funkcjonowania w kulturze. Nie sprzyja koncentracji i długotrwałej, zogniskowanej uwadze. Faworyzuje zaś elementy typowe dla zachowań istot „zaledwie” świadomych, takie jak: a) analizowanie wydarzeń w oderwaniu od szerszego kontekstu czasowo-przestrzennego; b) natychmiastowe nagradzanie; c) próbuje nieustannie odwracać i zawłaszczać naszą uwagę (co jest wynikiem nieustającej konkurencji medialnej); d) wykształca mechanizmy zbliżone do warunkowania, funkcjonuje dzięki skojarzeniom; e) bazuje bardziej na naturalnych skłonnościach aniżeli na oczekiwaniach wykształcanych społecznie (specjalizuje się raczej w przełamywaniu społecznych tabu); f) preferuje znacznie szybsze, choć mniej dokładne, strategie analizy - myślenie hasłami, obrazami; innymi słowy, procesy nielinearne (takie jak dialog czy praca $z$ tekstem) $z$ reguły są pomijane jako nużące. Odrzuca natomiast to, co typowe jest dla zachowań podmiotów samoświadomych: szerszy kontekst czasowo-przestrzenno-kulturowy i mniejszą koncentrację na „tu i teraz”, możliwość planowania, zakotwiczenie w tradycji kulturowej, wykształcanie oraz internalizację norm, a zarazem większe zorientowanie na cele wspólnoty. Jest egoistyczna - wspiera roszczeniowe nastawienie do świata.

5. Popkultura opiera się na interakcjach, których przeznaczenie jest zupełnie inne niż w przypadku kultury. Kultura jest bowiem całością złożoną ze znaczeń, zachowań, wartości, których celem jest przede wszystkim komunikowanie. W przypadku popkultury sprowadza się ono do transakcji o charakterze typowo handlowym. Nabywa się i konsumuje odpowiednie dobra, jednak nie muszą temu towarzyszyć szczególne normy czy tradycja.

6. Popkultura sama w sobie nie wykształca swojej historii, czym bliższa jest kulturom przedpiśmiennym niż społeczeństwom cywilizowanym. Nie istnieje coś takiego jak tradycja konsumowania. Nie istnieją również nurty zjawisk pop. Są one bowiem z reguły uśrednioną odpowiedzią na nasze naturalne potrzeby psychologiczne, zjawiska te są dedukowalne w pełni przez psychologię 
ewolucyjną. Zmiany w ramach masowych fenomenów kultury pop mają jedynie charakter ilościowy, nie jakościowy. Są one produktem, którego prawidła atrakcyjności wpisane są bardziej w naszą naturę aniżeli w kontekst kulturowy (zob. Szlendak, Kozłowski 2008).

7. Popkultura swym nastawieniem do uczestników zaprzecza podstawowej zasadzie zachowań kulturowych: nie wymaga od konsumentów brania pod uwagę punktu widzenia innych ludzi oraz zaufania. Zwraca się do wszystkich, choć do każdego $z$ osobna. Jest to jednoznaczne $z$ niezdolnością popkultury do wytworzenia najprostszych więzi.

8. Oferuje, co najwyżej, ułudę, „protezę” grup społecznych w postaci portali społecznościowych czy innych fikcyjnych całości, które tylko pozornie uwzględniają punkt widzenia innych użytkowników - w gruncie rzeczy jednak promują nachalną autoprezentację i zachowania typowo narcystyczne.

9. Może stawać się źródłem postaw aspołecznych lub antyspołecznych. Popularyzując przekaz eksponujący elementy przemocy i agresji przyczynia się do umacniania przekonania o tym, że świat jest zły i niesprawiedliwy, a ludzie wrogo nastawieni, gotowi każdego bezdusznie wykorzystać lub nawet pozbawić życia. Niejednoznaczne jest jej stanowisko względem elementów, które można uznać za wywrotowe dla porządku społecznego. Nietrudno wszak trafić na treści, które można odebrać jako nagradzające zachowania agresywne.

System, który reguluje życie w społeczeństwie informacyjnym (postindustrialnym, konsumpcyjnym, nazewnictwo jest tutaj zróżnicowane), z pewnością ewoluuje. Nie brakuje prac, które wskazują na zupełnie inną jakość i funkcje kultury wyłaniającej się z takiej całości (zob. np. Kerckhove 1996; Maj 2009). Pytanie jednak, w jakim stopniu uprawnione jest w dalszym ciągu nazywanie owych systemów kulturą, w jakim zaś - kulturą z dużą domieszką mechanizmów protokulturowych? Wiele decyzji konsumenckich daje się wyjaśnić za pomocą znacznie prostszych założeń, przewidywanych przez psychologię prymatów, bez odwołań do woli, mód czy samoświadomości, bardziej zaś do warunkowania i tresury. Nauki kognitywne wskazują na istotny przeskok między kulturą a protokulturą. Uwzględnienie tych ustaleń $\mathrm{w}$ dalszych rozważaniach nad popkulturą wydaje się o tyle istotne, że pomaga rozpoznać w niej to, co dzielimy z innymi ssakami naczelnymi, a także to, co — przynajmniej na pierwszy rzut oka - jest typowo ludzkie.

\section{BIBLIOGRAFIA}

Aitchison Jean, 2002, Ziarna mowy. Początki i rozwój jezzyka, tłum. Magdalena Sykurska-Derwojed, PIW, Warszawa.

Alba Joseph, Hutchinson Wesley, Lynch John, 1990, Memory and Decision Making, w: Handbook of Consumer Behavior, Thomas Robertson, Harold Kassarjian (red.), Prentice-Hall, New Jersey.

Barber Benjamin, 2008, Skonsumowani. Jak rynek psuje dzieci, infantylizuje dorostych i potyka obywateli, tłum. Hanna Jankowska, Muza, Warszawa. 
Baron-Cohen Simon, 1997, Mindblindness: An Essay on Autism and Theory of Mind, MIT Press, Cambridge, MA.

Bauman Zygmunt, 2007, Płynne życie, tłum. Tomasz Kunz, Wydawnictwo Literackie, Kraków.

Bergen Lori, Grimes Tom, Potter Deborah, 2005, How Attention Partitions Itself During Simultaneous Message Presentations, „Human Communication Research”, t. 31, s. 311-336 .

Blackmore Susan J., 2002, Maszyna memowa, tłum. Norbert Radomski, Dom Wydawniczy Rebis, Poznań.

D’Alessandro David F., 2001, Kreowanie marki: jak wypracować perfekcyjny wizerunek firmy i produktu, tłum. Magłorzata Malczyk, Agencja Wydawnicza Placet, Warszawa.

Damasio Antonio, 2000, Tajemnica świadomości. Jak ciało i emocje wspóttworza świadomość, tłum. Maciej Karpiński, Dom Wydawniczy Rebis, Poznań.

Damasio Antonio, 2002, Błąd Kartezjusza. Emocje, rozum i ludzki mózg, tłum. Maciej Karpiński, Dom Wydawniczy Rebis, Poznań.

Diamond Jared, 1998, Trzeci szympans. Ewolucja i przyszłość zwierzęcia zwanego człowiekiem, tłum. January Weiner, PIW, Warszawa.

Edelman George M., 1998, Przenikliwe powietrze, jasny ogień. O materii umystu, tłum. Joanna Rączaszek, PIW, Warszawa.

Fodor Jerry, 1983, The Modularity of the Mind: An Essay on Faculty Psychology, MIT Press, Cambridge.

Godzic Wiesław, 2007, Znani z tego, że sa znani. Celebryci w kulturze tabloidów, Wydawnictwa Akademickie i Profesjonalne, Warszawa.

Gopnik Alison, Meltzoff Andrew N., Kuhl Patricia K., 2004, Czego o umyśle ucza nas małe dzieci, tłum. Ewa Haman, Piotr Jackowski, Media Rodzina, Poznań.

Gorn Gerald, 1982, The Effect of Music in Advertising on Choice Behavior: A Classical Conditioning Approach, „Journal of Marketing”, t. 46, s. 94-101

Griffin Donald R., 2003, Umysty zwierząt. Czy zwierzęta maja świadomość?, tłum. Magda Ślósarska, Anna Tabaczyńska, Gdańskie Wydawnictwo Psychologiczne, Gdańsk.

Keen Andrew, 2007, Kult amatora. Jak Internet niszczy kulture, tłum. Małgorzata Bernatowicz, Katarzyna Topolska-Ghariani, Wydawnictwa Akademickie i Profesjonalne, Warszawa.

De Kerckhove Derrick, 1996, Odkrywanie nowej elektronicznej rzeczywistości, tłum. Witold Sikorski, Piotr Nowakowski, Mikom, Warszawa.

Kozłowski Tomasz 2007, Kłamię, więc jestem. W poszukiwaniu początków samoświadomości, Biblioteka Moderatora, Taszów.

Krzysztofek Kazimierz, 2007, Łebski świat: madrość tłumów sieciowych czy zbiorowe nieuctwo? Wprowadzenie, w: Keen Andrew, Kult amatora. Jak Internet niszczy kulture, tłum. Małgorzata Bernatowicz, Katarzyna Topolska-Ghariani, Wydawnictwa Akademickie i Profesjonalne, Warszawa.

Legutko Piotr, Rodziewicz Dobrosław, 2007, Gra w media. Między informacja a deformacją, Stentor, Warszawa.

Lifton Robert J., 1993, The Protean Self: Human Resilience in an Age of Fragmentation, Basic Books, New York.

Macphail Euan M., 2002, Ewolucja świadomości, tłum. Robert Bartold, Rebis, Poznań.

Maj Anna, 2009, Wikifizacja wiedzy, Travel 2.0 i globalhood, w: Anna Maj, Michał Derda-Nowakowski (red.), Kody McLuhana. Topografia nowych mediów, ExLibris, Katowice. 
Riesman David, 1971, Samotny tłum, tłum. Jan Strzelecki, PWN, Warszawa.

Rifkin Jeremy, 2003, Wiek dostępu. Nowa kultura hiperkapitalizmu, w której płaci się za każda chwilę życia, tłum. Ewa Kania, Wydawnictwo Dolnośląskie, Wrocław.

Sennett Richard, 2006, Korozja charakteru, tłum. Jan Dzierzgowski, Łukasz Mikołajewski, Muza, Warszawa.

Sennett Richard, 2009a, Upadek człowieka publicznego, tłum. Hanna Jankowska, Muza, Warszawa.

Sennett Richard, 2009b, Kultura nowego kapitalizmu, tłum. Grzegorz Brzozowski, Karol Osłowski, Muza, Warszawa.

Szlendak Tomasz, Kozłowski Tomasz, 2008, Naga matpa przed telewizorem. Popkultura $w$ świetle psychologii ewolucyjnej, Wydawnictwa Akademickie i Profesjonalne, Warszawa.

Sztompka Piotr, 2007, Zaufanie. Fundament społeczeństwa, Znak, Kraków.

Tomasello Michael, 2002, Kulturowe źródła ludzkiego poznawania, tłum. Joanna Rączaszek, PIW, Warszawa

Urbany Joel E., Dickson Peter R., Wilkie William L., 1989, Buyer Uncertainty and Information Search, „Journal of Consumer Research”, t. 16, s. 208-215.

Wilkie William L., 1994, Consumer Behavior, Wiley, New York.

Witkowski Tomasz, 2005, Inteligencja makiaweliczna. Rzecz o pochodzeniu natury ludzkiej, Biblioteka Moderatora, Taszów.

Wojak Przemysław, 2008, Jak przyciagnać uwage rozkojarzonego klienta?, „Harvard Business Review. Polska", nr 60, luty.

\section{ELEMENTS OF PROTOCULTURE TRANSMISSION WITHIN CONSUMER SOCIETY}

\section{Summary}

The article aims at focusing attention at selected aspects of pop culture which may, from the point of view of evolutionary psychologists, be deemed approximate to animal proto-cultures and social systems observed among the three-year-olds, i.e. people who have not yet developed a psychological skill called "theory of mind". The Author tries to point out that elements of proto-culture in the time of pop -industry development gain on dominance, as a result of which the quality of culture creating processes as well as culture transmission processes may be different than, let's say, fifty years ago. It is not only about the mass media, but it is most of all about deep psychological processes which are the basis for understanding the essence of culture and participation in culture. In other words, the author tries to argue that norms, ideas and values, i.e. what culture is made of in general - are understood and disseminated in ways which are different in quality from the ones prevailing in the past.

\section{Key words/słowa kluczowe}

culture / kultura; popculture / popkultura; proto-culture / protokultura; evolutionary psychology / psychologia ewolucyjna; theory of mind / teoria umysłu; emotions / emocje 